\title{
Re-making teacher professionalism in England: local professionalism and social responsibility
}

\author{
Rehaciendo el profesionalismo docente en Inglaterra: profesionalismo \\ local y responsabilidad social
}

\author{
Catharine Quirk-Marku y Moira Hulme'
}

\begin{abstract}
Teaching and teacher education in England have been subject to thirty years of sustained public scrutiny and political intervention (Furlong, 2013). A range of technologies have enhanced central control and promoted cultures of disciplined self-steering. These include systems of specification (through Teachers' Standards), measurement and comparison (through the audit of 'hard' performance indicators and periodic inspection of schools and teacher education), and prescribed forms of reflexive self-monitoring (quality assurance and evaluation processes). This article offers a critical analysis of the re-positioning of teaching and teacher education in England achieved by successive governments from the mid-1980s. Following a review of the trajectory of policies concerned with teacher development, three questions are addressed. How is teaching (re-)conceptualised in the reform of the Teachers' Standards in England? What emergent models of professionalism are discernible in recent drives to modernise and liberate the teaching profession? How do enduring models of 'occupational professionalism' (Evetts, 2011) interact with current moves towards localism in public service provision, diversification of school type and de-centralisation of education and children's services? The article concludes by identifying areas of tension between devolution of social responsibility and the promotion of local accountability, and the continued development of a national teaching service conceived as a public good.
\end{abstract}

\section{Keywords}

Teacher education, teacher evaluation, professional standards, accountability.

\section{Resumen}

Durante los últimos treinta años, la educación y la formación docente en Inglaterra han sido objeto del examen de la opinión pública y de la intervención política (Furlong, 2013). Tecnologías variadas han mejorado el control central e impulsado hábitos de autoformación disciplinada. Estas tecnologías incluyen sistemas de especificación (a través de las normas para docentes Teachers' Standards), evaluación y comparación (por medio de indicadores de desempeño «duros» en la auditoría e inspección periódica de escuelas y de la formación docente), y formas recomendadas de autoevaluación reflexiva (garantía de calidad y procesos evaluativos). El presente artículo ofrece un análisis crítico del reposicionamiento de la educación y la formación docente que se ha alcanzado en Inglaterra en el transcurso de gobiernos sucesivos desde mediados de la década de los 80 del pasado siglo. Después de repasar la trayectoria de políticas que atañen al desarrollo docente, se abordarán tres interrogantes. ¿De qué manera en Inglaterra se (re)conceptualiza la educación en la reforma que se plantea en las normas Teachers' Standards? ¿Qué modelos de profesionalismo se distinguen en avances recientes orientados a modernizar y liberar la profesión docente? ¿De qué manera los modelos de «profesionalismo ocupacional» (Evetts, 2011) interactúan con movimientos simultáneos hacia el localismo y la descentralización de la educación y los servicios de atención a la infancia? En la conclusión del artículo se identifican áreas de tensión entre la delegación de responsabilidades y la promoción de la responsabilidad local y el desarrollo sostenido del servicio nacional de educación, concebido como un bien público.

\section{Palabras clave}

Formación docente, evaluación docente, modelos profesionales, responsabilidad. 


\section{Introduction}

The level of political intervention in teaching and teacher education in England has evoked the term «policy hysteria» (Stronach and Morris, 1994). This article offers a critical interrogation of the reform strategies adopted by successive administrations. We argue that continuity in policy outcomes, irrespective of the party political composition of government, has resulted in significant recalibration of the location, content, and purposes of teacher education. The article considers the challenge to enduring traditions of occupational professionalism presented by accelerated diversification of school type and the progressive marketization of teacher education. The article is structured in four main sections. First, the regulation of teaching is outlined in key policy pronouncements from the White Paper Teaching Quality (DES, 1983) through to the influential The Importance of Teaching (DfE, 2010) and the most recent statement of intent, Educational Excellence Everywhere (DfE, 2016). Second, consideration is given to how the revision of professional standards in England has contributed to the (re-)construction of teaching as predominantly a technical craft, rather than an intellectual or ethical activity. Third, a critical reading of policy is offered drawing on a continuum from reductionist to contextualist conceptions of teacher professionalism (Murray and Maguire, 2007). Within this framework six extant variants of professionalism are identified: (i) democratic/collaborative (Sachs, 2003); (ii) national/managerial (Day and Sachs, 2004); (iii) occupational (Evetts, 2012); (iv) organisational (Moore and Clarke, 2016); (v) local; and, (vi) branded (Whitty, 2014). Finally, within this rapidly shifting context, the implications for English education of the recent promotion of permissive localism are considered.

\section{The reform of teacher education in England}

The neo-liberal principles of accountability, centralisation of control, performativity and marketization have profoundly shaped the education system in England. This section of the paper outlines how sustained intervention in the field of teacher education has eroded professional control and fragmented service provision. Successive Conservative governments (1979-97) imposed greater accountability and centralisation of control over the work of schools and school-university partnerships in Initial Teacher Training (ITT). Teacher education emerged as a policy problem to be managed by government in response to concerns over school standards. The White Paper Teaching Quality (DES, 1983) expressed concern about the quality of teaching. In 1984, a Council for the Accreditation of Teacher Education (CATE) was established with responsibility for overseeing ITT in England and Wales (circular 3/84 DES, 1984). Through the introduction of greater accountability mechanisms CATE signalled a shift from «government to governance» (Exley 2016: 743). Whilst academic validation remained with the universities and the Council for National Academic Awards (CNAA), the task of making recommendations to the Secretary of State on the approval of courses leading to Qualified Teacher Status (QTS) - professional accreditation - was now held by a single national body.

Further regulation followed including specification of the amount of time that a trainee teacher needed to spend in school (circular 3/84 DES, 1984); topics that all ITT courses had to cover; and the «outputs» that trainee teachers had to know or be able to do (circular 24/89 DES, 1989). Furlong et al., (2000: 14) noted the progressive strengthening of a «national framework of accountability». A «culture of accountability» (Menter 2015: 3) developed in schools in response to the demands of the newly established Office for Standards in Education (Ofsted). This regulatory body was responsible for the inspection of all maintained schools and ITT courses in England, effectively replacing regional local authority 
inspectorates. Inspection under Ofsted was more directive, emphasising the quality of teaching as much as the quality of learning. The Chief Inspector of Schools in England, Chris Woodhead (who held the post from 1994 to 2000), maintained a barrage of public criticism of «incompetent teachers» and «failing schools.» Government intervention in teacher education accelerated. In 1994, the Teacher Training Agency (T'TA), (subsequently renamed the Training and Development Agency for schools), was established to oversee the supply and recruitment of teachers, the funding of teacher education in England, and the accreditation of ITT courses. Funding of teacher training was now separated from other higher education funding. Universities/colleges needed to bid for TTA funding as «providers» of teacher education; effectively creating a quasi-market in IT'T.

Continuity with the previous Conservative administration's commitment to centralisation and performance management is discernible in the policy portfolio of successive Labour administrations at Westminster (1997-2010). In some cases, new Labour extended the centralisation of ITT. A five-page national curriculum for teacher training was implemented in 1997 which specified in detail the content that had to be covered by trainee teachers in English language, mathematics, science and Information and Communications Technology (ICT) (Whitty, 2006). The prescribed ITT curriculum was replaced in 2002 by an overarching Qualifying to Teach framework that set minimum legal requirements for IT'T providers.

The above trajectory of external accountability was sustained by the Conservative-Liberal Democrat coalition government (2010-15), while also extolling the virtues of professional autonomy. The White Paper The Importance of Teaching (DfE, 2010:28) sought to «free headteachers and teachers from bureaucracy and red tape (and help them feel empowered to do what they think is right, whilst ensuring that schools) are accountable for the results they achieves (DfE, 2010: 28). However, this language of empowerment sits within an approach that demands thorough accountability and close surveillance by national government. In a speech at the National College annual conference (2010) the then Education Secretary, Michael Gove, stated that he was «passionate about extending the freedoms denied to you by the last government», described the increasing number of autonomous schools (academies, studio schools and free schools) as «tugboats adding extra pull to the drive to increase universal standards.» However in this speech Gove also stated that «Intervention should be in inverse proportion to success... Ofsted's resources (will be directed) to those schools which are faltering» (2010). The ability for professionals to exercise autonomy is tightly regulated and subject to external intervention if performance targets are not met.

The marketization of ITT was advanced most radically by the introduction of the School Direct programme in 2011. Under this model, maintained schools (rather than universities) recruit prospective teachers directly and 'buy in' university accreditation via 'training contracts'. The School Direct scheme reflects the commitment of the then Education Secretary that «schools should play a greater role in leading the recruitment, selection and training of teachers» (DfE, 2011, p.11, paragraph 3.1). The introduction of School Direct, in addition to the smaller schemes - Teach First (modelled on Teach for America), Teach Now, Troops into Teaching, Researchers in Schools - and the long-standing School-Centred Initial Teacher Training (SCIT'Ts), has accelerated moves towards a school-based and school-led system of teacher education (Taylor, 2013). The pace of change has been rapid. Between 2011 and 2016, the number of routes into teaching for prospective trainees increased from four to eight. In line with the policy objective of expanding school-led training, the number of school-centred providers increased from 56 to 155 . The number of schools leading School Direct rose from zero to over 800 (Committee of Public Accounts, 2016: 4). 
The involvement of a wide range of new providers of ITT created great instability across university Schools of Education in England. The period from 2012 has been turbulent with some university providers withdrawing from teacher education altogether. In 2015, the government moved away from advance allocations of IT'T places and imposed a national limit, which once reached led to a recruitment cap. This experiment incentivized providers to recruit early in the year rather than invest time in attracting the highest quality of candidates. Multi-year allocations were re-introduced in 2017 but only for the 'best' IT'T providers according to certain criteria: degree class of trainees; quality of training as assessed by Ofsted; proportion of trainees employed in teaching within two years of qualification; and recruitment against previous allocation of training places. These measures introduce a further element of competition among providers and instability for those providers who do not secure year-on-year protected allocations. The government's preferred strategy to address a growing problem of teacher shortages - in particular regions of England and in particular subject areas - is to use the allocations methodology to promote regional consortia of School Centred ITT providers (SCITTs) with the capacity to train a high volume of trainees quickly in response to local needs. In this adverse climate, the university contribution to ITT in England may contract further in the coming years.

The level of political intervention peaked during the tenure of Michael Gove as Secretary of State for Education (2010-2014). The intensity of reform eased a little, if not the pace of change, during the terms in office of Nicky Morgan MP (2014-2016) and Justine Greening MP (July 2016-). However, the direction of travel towards a school-led system of ITE remains constant. An independent review of the quality and effectiveness of IT'T courses in England (DfE, 2015) produced further guidance on: (i) content for the ITT curriculum; (ii) behaviour management content; and, (iii) standards for school-based mentors (DfE, 2016). In 2017, the Westminster Government introduced an apprentice levy to support vocational training in the UK. Teaching is included within this new apprenticeships scheme. Draft $A p$ prentice Teacher Standards have recently been published i.e. the job role that an apprentice will be doing and the skills required of them (ESFA, 2017). For traditionalists, this development may be seen as a further erosion of the professional status of teachers in England.

The above review of the reform of teacher education in England over the last three decades shows the progressive exertion of central control over teacher education and teachers' work. This movement reached its zenith during the period of 'muscular liberalism' advanced in David Cameron's (2011) defence of British values and championed by England's most controversial Secretary of State for Education, Michael Gove MP. The distinctly neo-liberal agenda for the reform of teacher education in England (DfE, 2010) is also evident in the United States (National Council on Teacher Quality, 2013) and Australia (TEMAG, 2014). These reforms share a concern with addressing teacher quality by strengthening the professional experience component of initial teacher training, and using statutory Standards to assure compliance with an external quality regime. The following section offers a critical examination of how the Teachers' Standards in England have been used as regulatory devices to hold professionals to account for particular types of performance.

\section{How teaching is (re-)conceptualised in the reform of the Teachers' Standards}

Professional standards in teaching are context dependent and reflect different conceptualisations of what it means to be a 'good' or 'good enough' teacher. The rationale, content and underpinning philosophy of teachers' Standards reflect who has the authority to shape official discourse - the profession and/or government. 
National professional standards for teachers in England were first introduced in 1998 and were subject to significant revision in 2002, 2007 and 2011. The first iteration of standards was roundly criticised for being «regulatory» rather than «developmental» in intent (Mahony and Hextall, 2000). The Standards were organised in three inter-related sections: professional values and practice; knowledge and understanding; and teaching (planning, monitoring and assessment, and class management). Computerised skills tests were introduced for beginning teachers in numeracy, literacy and ICT in 2001. The 2007 professional standards framework comprised a set of five standards for different career stages: (i) standards for the award of Qualified Teacher Status (new teachers); (ii) Core Standards (for teachers on the main pay scale); (iii) higher level standards for Post-Threshold teachers (giving access to the upper pay scale after five years subject to local Threshold assessment); (iv) Excellent Teacher, and, (v) Advanced Skills Teacher (externally assessed). The post of Advanced Skills Teacher, introduced in 1998, was an alternative career path distinct from management with an explicit outreach role. In addition, an Excellent Teacher scheme was established in 2006 for accomplished teachers without an outreach commitment.

Soon after the General Election in 2010, the UK coalition government announced a review of Teachers' Standards in England. The Review was completed in just six weeks and led to a reduction from 33 to 8 baseline standards for Qualified Teacher Status (QTS). The Review Group did not have representatives from university Schools of Education. The revision of the teachers' Standards was part of a wider critique of 'progressive educational theory' that positioned university-based teacher educators as «enemies of promise« (Gove, 2013). Launching the review of Teachers' Standards, the Department of Education insisted that «[i]nstead of focusing on the essential skills of great teaching, the current standards are a vague list of woolly aspirations» (Department of Education press release, 11 March 2011). Responding to the publication of the first report of the review group, Michael Gove argued that « $[\mathrm{t}]$ he old standards placed a premium on bland statements and platitudes over practical use for teachers» (Department of Education press release, 14 July 2011). In accepting the recommendations of the review, Gove argued that the core Standards implemented from 2012 would, «set clear expectations about the skills that every teacher in our schools should demonstrate... They will make a significant improvement to teaching by ensuring teachers can focus on the skills that matter most» (op cit). The revised Standards make no explicit mention of teachers' professional responsibility to engage with or in research (Beauchamp et al., 2015).

«Teaching is a craft and it is best learnt as an apprentice observing a master craftsman or woman. Watching others, and being rigorously observed yourself as you develop, is the best route to acquiring mastery in the classroom.» (Gove, 2010: 6)

The second report, published in December 2011, reviewed the higher-level standards - Post-Threshold, Excellent and Advanced Skills. The report recommended the replacement of this set of pay standards with a single «Master Teacher Standard.» This Standard would be expressed «in the form of a narrative statement, setting out the characteristics of excellent teachers (Independent Review of Teachers' Standards, 2011: 6) and its achievement would involve external assessment. However, while the Secretary of State agreed in principle to the Master Teacher Standard for accomplished teachers, this has not progressed. Conversely, the career structure for qualified teachers has flattened, non-qualified graduate teachers are now permitted to work in free schools and academies (i.e. maintained schools that are independent of local authority control), and the new grade of Apprentice Teacher is soon to be introduced. 
"Reductions in public funding are managed by reallocating elements of the traditional work of the public service professions to a less costly and more easily controlled labour force, whilst mobilising a disciplinary discourse of 'acting professionally' tied to managerial accountability.» (Colley and Guéry 2015: 114)

It is difficult for teachers and teacher educators to work against the grain of the competencies discourse. Standards are productive as well as evaluative, providing parameters for officially endorsed action or ways of being a «good teacher» (Moore, 2004). The Standards specify approved behaviours that constitute good practice. Evans (2011) argues that the new Standards offer «a professionalism that focuses predominantly on teachers' behaviour, rather than on their attitudes and their intellectuality» (851). Roberts et al. (2006) have explored the ways in which demonstrating achievement of the Standards involves careful acts of «fabrication» (Ball, 2001). Although it is the emotional and relational, rather than competence-related dimensions of professional learning, that present the greatest challenge in the early experiences of teaching, it is the performative dimensions that beginning teachers attend to as they work with mentors to achieve performances that 'meet the standards' - carefully assembling together presentations of the 'performing' and 'conforming' teacher. The employment of teachers in free schools, studio schools and academies without qualified teacher status or a postgraduate certificate in education (PGCE), at a lower locally determined pay grade, further incentivises compliance.

Drawing on the historical review outlined above, the next section positions the range of discourses currently on circulation within a framework for understanding professionalism. We acknowledge that professionalism is «an essentially contested concept» (Hoyle and John, 1995: 1) and that «definitions of professionalism vary across time and place» (Whitty, 2012: 28). In the section below, we draw attention to the entanglement of multiple discourses and locate different conceptualisations of professionalism depending on the extent to which they are context dependent or context indifferent, and promote higher or lower levels of teacher autonomy (Figure 1).

\section{A framework of different approaches to professionalism}

The following typology locates different approaches to professionalism in relation to one of two theoretical discourses. The first is labelled by Murray and Maguire (2007) as a reductionist or essentialist discourse and is based on the premise that there are a set of competencies that need to be learnt by the professional and then subsequently applied with fidelity in practice irrespective of context. Murray and Maguire (2007) argue that a reductionist discourse «operates to simplify a complex field» (284) and to exclude alternative discourses that challenge its hegemony. Hoyle (1982) argues that the essentialist approach to professionalism is a process whereby an occupation or professional «increasingly meets the criteria attributed to a profession» (161). In achieving this goal a Faustian pact is made. In codifying a decontextualized set of skills and discrete knowledge base for teaching, the work of teachers adopts a technicist character, stripped of its ethico-political content.

In contrast, Murray and Maguire (2007) highlight the importance of an alternative contextualist discourse, described by Locke et al., (2005) as a social constructionist approach. This approach is explicit about, and responsive to, the context and historical framework it exists in and intentionally considers the inter-relationships between macro-level policy change, and individual and collective practice. Murray and Maguire (2007) argue that a contextualist discourse is based on the principles that the professional has integrity 
and is reflective, and that the training of the professional is highly sensitive to the context and designed to develop his/her diverse (rather than standardised) human capabilities.

Reductionist and contextualist discourses are conceptualised here as a continuum, rather than as a dualism. A matrix of teacher professionalism (Figure 1) with axes of contextualist/reductionist discourse and high/low teacher autonomy provides a flexible framework on which to place different approaches to professionalism. High/low teacher autonomy refers to the degree of autonomy the professional is able to exercise which is highly dependent on the external controls exerted by policy documents, politicians and by his/her employer. There are a myriad of different approaches to professionalism that can be plotted on this matrix and six are selected for attention here: democratic or collaborative professionalism (Sachs, 2003), national or managerial professionalism (Day and Sachs, 2004), occupational professionalism and organisational professionalism (Evetts 2011; 2012; Moore and Clarke, 2016), local professionalism and branded professionalism (Whitty, 2014).

\section{Figure 1: Matrix of teacher professionalism}

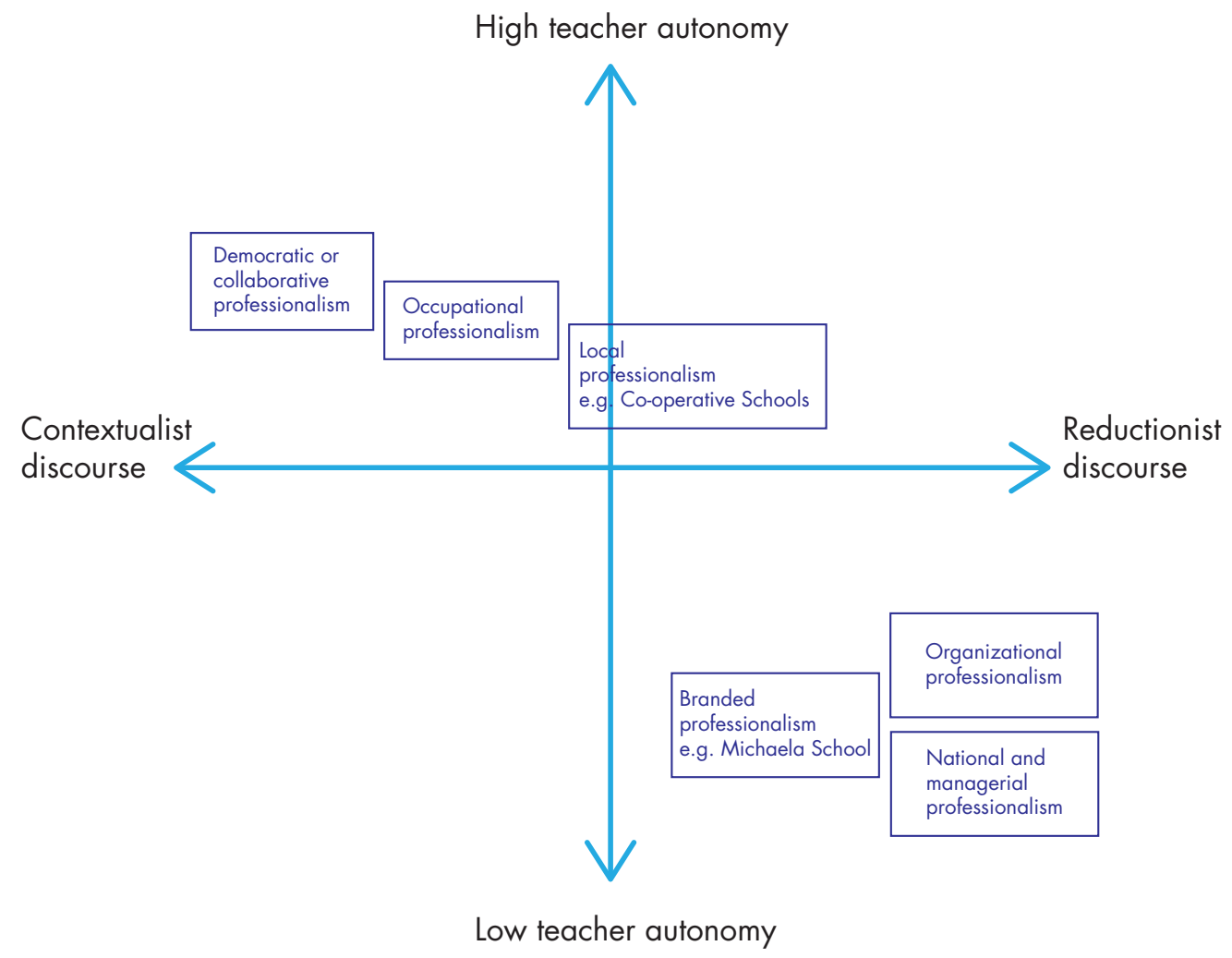

High levels of autonomy are a feature of democratic or collaborative professionalism (Whitty and Wisby, 2006; Sachs, 2003). Democratic professionalism views the professional as an 'activist' where the professional makes things happen rather than lets things happen to him/her (Sachs, 2003). This concept of the 'activist' professional operates successfully in a context of democratic localism. Democratic professionalism requires professional networks and professionals who collaborate beyond their workspace, including with their students, parents, members of the community and health professionals. This approach to professionalism has also been labelled extended professionalism (Hoyle, 1982) and the community teacher approach (Zeichner, Payne and Brayko, 2015). 
In contrast, national professionalism (Whitty, 2014) places the locus of control in the hands of the national government and is imposed from above on the professional. This approach to professionalism is based on an essentialist approach in which there are a set of criteria against which the conduct of a professional can be measured. Hoyle (1982) describes this as a criterion approach. The successful professional in this approach is the one who efficiently and effectively meets the standardized criteria and contributes to the school's formal accountability process. Stevens (2010) describes this approach as an 'obedience' approach to professionalism; Evans (2008) labels it 'prescribed' or 'demanded' professionalism. The micro-management, standardization, assessment and performance reviews that are an integral to national professionalism contribute to de-professionalisation because teachers' judgment and discretion are diminished.

«Organizational objectives (which are sometimes political) define practitioner/ client relations, set achievement targets and performance indicators. In these ways organizational objectives regulate and replace occupational control in practitioner/client work interactions thereby limiting the exercise of discretion and preventing the service ethic that has been so important in professional work.» (Evetts, 2012: 6)

The assessment practices in this approach are based on meeting the standards and on pupils achieving their target grades which will consequently lead to the school being placed high in the league tables and achieving well against the 'hard' performance indicators set by government.

Evetts (2012) identifies a shift from occupationalprofessionalism (owned by the profession) to organisational professionalism as a consequence of de-centralisation and New Public Management (NPM) in schools. It is not our intention here to naively valorise occupational professionalism as an ideal type. The model of occupational professionalism presents the teaching body as homogenous rather than diverse and stratified (by gender, ethnicity, age, region, sector, curriculum specialism and education). Arguably this vision of teaching was developed by an elite within the profession to promote their «own occupational self-interests in terms of their salary, status and powens (Evetts, 2011: 410). From a critical perspective, the decline of occupational professionalism reflects the erosion of influence of organised established interests vis-à-vis political reformers advancing the localism agenda.

Whitty (2014) argues that the direction of education policy during the coalition government (from 2010) signalled a move away from national professionalism, in which for example teaching standards are centrally devised, applied and regulated, towards local professionalism and branded professionalism. Local professionalism is an approach in which schools work as a consortium to develop their own approaches. However, local professionalism remains less common today in England than branded professionalism because of the increase in multi-academy chains (MATs), competition amongst local schools, and budget cuts to local authorities facilitating local networks. Individual schools or academy chains that promote a distinctive approach to teaching and train only the types of teachers they want employ the approach of branded professionalism. Whitty (2014) argues that local and branded professionalism may replace national professionalism. However, schools need to meet central criteria and accountability measures and therefore operate a form of local or branded professionalism within a frame of national professionalism.

Given the importance of local discretion, albeit bounded, it is not possible to plot the diverse range of branded and local professionalisms precisely on the matrix. Some school clusters and academy chains offer more autonomy and opportunities for democratic professionalism than others. Context matters. For illustrative purposes, we contrast one selected example of local professionalism, the Co-operative Trust Schools; with one example of branded professionalism, the Michaela School. 
Co-operative Trust Schools emerged in 2008 as a new model of school governance in England. Schools that adopt this model transfer their land and assets to a locally-run charitable trust and subscribe to the values of the global co-operative movement, including democracy and equality. Democratic accountability is pursued through membership. The stakeholders in the school (i.e. parents, carers, staff, students and local people) can become members and elect representatives to the trust board. The trust board holds the school to account. Co-operative Trust Schools often sign up as a cluster of local schools and share experience and resources; drawing parallels with democratic professionalism. Whilst the Co-operative model of local professionalism embraces the values of democracy and equality it also operates in England within a frame of national professionalism, with its associated culture of performativity and accountability demands, and is consequently plotted closer to reductionist discourse. The global co-operative movement's values, governance, philosophy and approach offer more autonomy for teachers and the local community and therefore place it closer to high autonomy on the matrix.

The Michaela School free school is an example of branded professionalism. The coalition government encouraged parents and independent groups in England to set up their own schools, called free schools, which are funded directly by central government and run as a not-for-profit organisation. Free schools are exempt from teaching the national curriculum and have increased control over teachers' pay and conditions and the length of school terms and days. It should be noted that the Michaela School is not typical of free schools and has attracted a high level of media attention for practices that are often deemed controversial. It is used here as one illustrative example of the exercise of new freedoms at a local level. Michaela School has a longer school day than many English schools, from 7:30am to 4pm. The governing body of the school includes representation from staff and parents, as well as the Directors of the free school. This provides some element of local (site-based as opposed to community) democracy and a degree of influence among some teachers in the school. However, the school has a tightly prescribed set of values, curriculum, and expectations for students and teachers that suggests low levels of professional autonomy for most teachers. As a free school, Michaela School is not required to deliver the national curriculum but it still is required to deliver the academic qualifications, publish its results and the schools inspectorate, Ofsted, inspects it. Whilst the Directors of the free school have autonomy to develop a curriculum and a culture that offers a bespoke brand of professionalism, the school and its teachers operate within a structure of national professionalism and have to meet many of its incumbent performativity and accountability demands. For these reasons, this specific and distinctive example of branded professionalism is plotted on the matrix closer to reductionist discourse and low teacher autonomy.

Differing approaches to professionalism do not emerge consecutively but continue to circulate alongside each other, with particular models gaining traction at specific junctures. The quasi-marketization of ITT has developed hybrid forms of professionalism; for instance where branded professionalism operates within a frame of national professionalism. Policy makers work with the legacy of previous regimes and policy texts are frequently multi-voiced. For example, A Framework of Core Content for Initial Teaching Training (DfE, 2016) - which sets out the standards that trainee teachers will need to meet - can be seen as reductionist, grounded in a managerial approach to professionalism. However, the document was the outcome of a working group of school leaders and recommends that the core content for ITT should not be «overly prescriptive and (should) leave room for ITT providers to use their professional judgement and expertise" and for "innovation in the design and delivery of ITT» (DfE, 2016: 7). The exercise of local discretion by schools within an enduring accountability framework is sometimes referred to as 'autonomy within high walls' or 
'steering at a distance'. The renewed interest in localism in government policy for schools raises interesting challenges for educators who would seek to use new freedoms to enhance local democracy. The following section explores how the approaches to professionalism outlined above find expression in the recent advance of liberal localism in education.

\section{Localism and social responsibility}

As noted above, there have been some recent moves towards permissive localism in education and the development of the education workforce in England. The revitalisation of Conservative politics in England before 2017 gave rise to liberal localism in public service provision. From 2010, there has been a modest retreat from over-controlling performance management with greater emphasis on self-regulation through continuous self-evaluation, supported by periodic inspection. School improvement is pursued through rigorous forms of self-evaluation. Decentralisation and devolution of control to the local level, combined with diversification of school type, ostensibly create the conditions for innovation and locally owned improvement action. From this perspective, the task of government is to help individuals to play the role of actor in his or her own life i.e. the maximisation of liberty. The Schools White Paper, The Importance of Teaching (DfE, 2010) makes repeated references to 'new' freedom(s), and 'retaining', 'renewing' or 'restoring' individual and institutional freedom(s). Intervention is only necessary as far as it creates local conditions for responsible self-government. There are recurrent references to the need to remove «Ministerial interference» (DfE, 2010: 11) and the «unnecessary prescription and bureaucracy» (DfE, 2010: 28) that has «fettered discretion» (DfE, 2010: 13). Change is necessary because schools are «constrained by government directives» (DfE, 2010: 8) that have placed a «bureaucratic burden on school» (DfE, 2010: 9).

"It is only through reforming education that we can allow every child the chance to take their full and equal share in citizenship, shaping their own destiny, and becoming masters of their own fate... to choose a fulfilling job, to shape the society around them... to become authors of their own life stories.) (Michael Gove, DfE, 2010: 6)

However, the reform of teaching and teacher education has progressed in inauspicious circumstances. In a time of deepening inequality and social polarisation, critics have branded the agenda for change «austerity localism« (Featherstone et al., 2012). Schools and teachers are positioned as sources of blame and recovery in response to a manufactured crisis (Slater, 2015). From this perspective, the political narrative of localism expounded by the Cameron governments (2010-2016) - associated with the Big Society, new civicism, voluntarism and citizenship empowerment - becomes another means to responsibilise and individualise. The political ideology of conservative localism has gained force in England as alternatives readings - such as democratic or progressive localism - are marginalised or colonised. The silencing of alternative narratives has been referred to as the «symbolic annihilation» (Spencer, 2013) of progressive educational politics within public discourse. Paradoxically, the latest iteration of localism demands a radically reduced role for local government as the arbiter of potentially competing local interests. The White Paper Educational Excellence Everywhere (DfE, 2016) suggested that by 2022 locally elected authorities would have no role in maintaining schools and academy trusts would no longer be required to have elected parents on their governing bodies. The key agents for change are intended to be Teaching School alliances, National Leaders of Education and multi-academy trusts (MATs) with support from Ofsted, the schools inspectorate.

A contextualist reading of recent policy change would point to the persistence of structural and systemic inequalities that are obscured in liberalism's attention to individual agency, autonomy and choice- 
making. Within current political discourse, insufficient consideration is afforded to how material inequalities may restrict liberty. A pernicious 'will to empower' has a number of deleterious consequences for individuals, schools and communities. The narrative of the enterprising career teacher normalises long hours and competitive behaviour (valorised in some forms of local professionalism), and obscures the role of cultural capital in reproducing social inequality and career hierarchies. The representation of 'the' teacher ignores important issues of gender, age and background. The alternative pathway to qualification for elite candidates, Teach First, positions teaching as a short-term personal advancement exercise. While autonomy-driven school improvement is a laudable goal, diversification of school type may increase social segregation that is a known barrier to social mobility. Fair access for all students to high performing community schools is not assured in the new schools landscape. Indeed further diversification - via free schools, studio schools and university technical colleges - is likely to exacerbate rather than address longstanding issues of educational inequity in an English education system that has never been fully comprehensive.

The aspirations of the Localism Act 2012 are undermined by a lack of commitment to national redistribution and regional social justice. England is an outlier within UK in its neglect of inclusive growth strategies to address growing social and economic polarisation. Elsewhere in the UK, area-based, 'total place' and 'whole population' stances have attempted to challenge the fragmentation of service delivery produced by marketization and contracting out. Such strategies challenge the assumption that essentialist or teacher-centric approaches will be sufficient in successfully addressing educational inequity. In contrast, the erosion of professional silos in service provision is sought through the integration/coordination of health, education, social care and youth justice services. Much might be learned from the advocacy of place-based learning and community teachers in addressing social disadvantage (Kretchmar and Zeichner, 2016). However, this would demand a radical re-envisioning of the dominant discourse of professionalism in England from its current emphasis on individual liberty to a re-conceptualisation that foregrounds social responsibility. An alternative construct posited by Fasoli, Scrivens, and Woodrow (2007) is one of 'sustainable professionalism' underpinned by 'ethical entrepreneurship' that «starts with a belief in social justice, making a difference and taking some action that contributes in a strategic way to the wellbeing of children, families, community and colleagues» (244).

\section{Conclusion}

The reform of teacher education and teachers' work in England over the last thirty years reveals a pattern of sustained political intervention and central steering, marketization and fragmentation. In 1998 there were 72 universities accredited to provide initial teacher training in England. In 2017, there are in excess of two hundred accredited providers of all sizes and differing institutional affiliations. The ITT landscape in England now includes universities, School Centred Initial Teacher Training (SCITTS), schools and multi-academy trusts working together with a university, or alone via the School Direct programme. Assuring any consistency of experience for beginning teachers in such a diverse market poses a significant challenge. The diversity of pathways to qualification, involving different types of school with different governance arrangements, raises questions about the integrity and coherence of the profession. Volatility in the allocation of training places, compounded by experiments that have led providers to concentrate on the pace of recruitment rather than the quality of the applicant, have compounded difficulties. The introduction of Apprentice Teacher roles in 2017 may be regarded as signalling the further de-professionalization of teaching in England. The proliferation of providers, and the emergence of multiple forms 
of local and branded professionalism, raises the question of the values base that informs new and hybrid models of professionalism. In this fragmented landscape, what are teachers in differing settings accountable for and to whom?

From a critical perspective, the Standards discourse entails the enfolding of external authority in teacher self-making. Creating space for alternative narratives in this context is problematic. As Clarke and Phelan (2017) note, «No one wants to be thought of as 'sub-standard' or to explicitly claim to be against standards or to speak in favour of unaccountability» (25). Pressure to comply produces accommodation, and sometimes enthusiastic endorsement of processes of economization, commodification and standardisation in education (Ball, Maguire and Braun, 2012). Moore and Clarke (2016) lament the 'cruel optimism' at work when educators take on the stylised identity of the modern professional committed to forms of continuous striving for improvement that paradoxically impoverishes the very professionalism they seek to embody.

If teaching in the maintained sector is positioned as a public service contributing to the public good, then deliberation on professionalism remains ever urgent. Renewed interest in localism may suggest new possibilities to enact more democratic forms of locally sensitive professionalism. However, the model of the citizen-teacher enshrined in democratic professionalism requires strong versions of local democracy; this demands a substantive shift from hierarchical to relational forms of accountability (Moncrieffe, 2011). The prospects for such developments are not encouraging in post-Brexit 2017 England. Democracy is not deepened by diminished parental representation on school governing bodies, the removal of elected local authorities from school governance, or by contracting out the delivery of public education services to private providers. In this version of localism, responsibility is devolved to non-elected private bodies rather than empowering local communities (or mini-publics). The English experiment in marketization in public education has produced diversification and innovation, but centrally orchestrated localism is a weak conduit for educational democracy.

\section{Bibliographic references}

Ball, Stephen J. (2001): "Performativities and fabrications in the education economy: towards the performance society" in D. Gleeson \& C. Husbands (eds.). The Performing School: Managing Teaching and Learning in a Performance Context. London: Routledge Falmer.

Ball, Stephen J.; Maguire, Meg \& Braun, Annette (2012). How Schools Do Policy. London: Routledge.

Beauchamp, Gary; Clarke, Linda; Hulme, Moira \& Murray, Jean (2015): “Teacher Education in the UK Post Devolution: Convergences and Divergences”. Oxford Review of Education, 41 (2), 154-170, doi: 10.1080/03054985.2015.1017403

Cameron, David (2011). PM’s speech at Munich Security Conference, 5 February [online] Accessed 21/06/17 from: https://www.gov.uk/government/speeches/pms-speech-at-munich-security-conference

Clarke, Matthew \& Phelan, Anne M. (2017). Teacher Education and the Political. The Power of Negative Thinking. London: Routledge.

Colley, Hellen \& Guéry, Frédérique (2015): “Understanding new hybrid professions: Bourdieu, illusio and the case of public service interpreters". Cambridge Journal of Education, 45 (1), 113-131, doi: 10.1080/0305764X.2014.991277 
Committee of Public Accounts (2016). Training New Teachers, HC73, London: House of Commons.

Day, C., \& Sachs, J. (2004): "Professionalism, performativity and empowerment: Discourses in the politics, policies and purposes of continuing professional development" in C. Day \& J. Sachs (eds.). International handbook of continuing professional development of teachers. Maidenhead, UK: Open University Press.

DES [Department of Education and Science] (1983). Teaching Quality. London: DES.

DES [Department of Education and Science] (1984). Initial Teacher Training: approval of courses. Circular 3/84. London: DES.

DES [Department of Education and Science] (1989). Initial Teacher Training: approval of courses. Circular 24/89. London: DES.

DfE [Department for Education] (2010). The Importance of Teaching. London: DfE.

DfE [Department for Education] (2011). Training our next generation of outstanding teachers. London: DfE.

DfE [Department for Education] (2011, 11 March). Press release - Major overhaul of qualifications to raise the standard of teaching. London: DfE.

DfE [Department for Education] (2015). Carter Review of Initial Teacher Training. London: DfE.

DfE [Department for Education] (2016). A framework of core content for Initial Teacher Training. London: DfE.

DfE [Department for Education] (2016). Educational Excellence Everywhere. London: DfE.

Education and Skills Funding Agency (2017). Apprenticeship Standards. [online\} Accessed 21/06/17 from https://www.gov.uk/government/uploads/system/uploads/attachment_data/file/607590/Apprenticeship_standards_April_2017.pdf

Evans, Linda (2008): "Professionalism, professionality and the development of education professionals". British Journal of Educational Studies, 56 (1), 20-38, doi: 10.1111/j.1467-8527.2007.00392.x

Evans, Linda (2011): “The 'shape' of teacher professionalism in England: professional standards, performance management, professional development and the changes proposed in the 2010 White Paper". British Educational Research Journal, 37 (5), 851-870, doi: 10.1080/01411926.2011.607231

Evetts, J. (2011): “A new professionalism? Challenges and opportunities”. Current Sociology, 59 (4), 406422, DOI: $10.1177 / 0011392111402585$

Evetts, J. (2012): “Professionalism in Turbulent Times: Changes, Challenges and Opportunities". Propel International Conference, Stirling University, 9-11 May 2012.

Exley, Sonia (2016): “'Critical friends': exploring arm's length actor relationships to local government in education”. Journal of Education Policy 31 (6), 742-756, doi: 10.1080/02680939.2016.1166523

Featherstone, David; Ince, Anthony; Mackinnon, Danny; Strauss, Kendra and Cumbers, Andrew (2012): "Progressive localism and the construction of political alternatives". Transactions of the Institute of British Geographers, 37, 177-182, DOI: 10.1111/j.1475-5661.2011.00493.x

Fasoli, L., Scrivens, C. \& Woodrow, C. (2007): “Challenges for Leadership in Aoterea/New Zealand and Australian Early Childhood” in Keesing-Styles, Linda \& Hedges, Helen (eds). Theorising Early Childhood Practice: Emerging Dialogues. Sydney: Pademelon Press. 
Furlong, John (2013): “Globalisation, Neoliberalism, and the Reform of Teacher Education in England”. Educational Forum, 77 (1), 28-50, doi: 10.1080/00131725.2013.739017

Furlong, John; Barton, Len; Miles, Sheila; Whiting, Caroline and Whitty, Geoff (2000). Teacher Education in Transition: re-forming professionalism? London: Open University Press.

Gove, Michael (2010). Michael Gove at the National College annual conference (on line). http://www. education.gov.uk/inthenews/speeches/a00210308/michael-gove-at-the-national-college-annual-conference, accessed 16 December, 2016.

Gove, Michael (2013, 23 March): "I refuse to surrender to the Marxist teachers hell-bent on destroying our schools: Education Secretary berates 'the new enemies of promise' for opposing his plans". The Daily Mail (on line). http:/ /www.dailymail.co.uk/debate/article-2298146/I-refuse-surrender-Marxistteachers-hell-bent-destroying-schools-Education-Secretary-berates-new-enemies-promise-opposingplans.html, accessed on 15 January 2017.

Hoyle, Eric (1982): “The professionalization of teacher: a paradox”. British Journal of Educational Studies, 30 (2), 161-171, doi: 10.2307/3121549

Hoyle, Eric \& John, Peter D. (1995): “The idea of a profession.” in Eric Hoyle \& Peter D. John (eds.). Professional knowledge and professional practice. London: MacMillan.

Independent Review of Teachers' Standards (2011). Second Report of the Independent Review of Teachers' Standards. London: DfE.

Kretchmar, Kerry \& Zeichner, Ken (2016): “Teacher prep 3.0: a vision for teacher education to impact social transformation". Journal of Education for Teaching, 42 (4), 417-433.

Locke, Terry; Vulliamy, Graham; Webb, Rosematy \& Hill, Mary (2005): “Being a 'professional' primary school teacher at the beginning of the $21^{\text {st }}$ century: a comparative analysis of primary teacher professionalism in New Zealand and England”. Journal of Education Policy, 20 (5), 555-581, doi: $10.1080 / 02680930500221784$

Mahony, Pat, \& Hextall, Ian (2000). Reconstructing teaching: Standards, performance and accountability. London: Routledge Falmer.

Menter, Ian (2015): "Introduction." in Teacher Education Group (ed.). Teacher Education in times of Change. Bristol: Policy Press.

Moncrieffe, Joy (2011). Relational Accountability: Complexities of Structural Injustice. London: Zed Books.

Moore, Alex (2004). The Good Teacher: Dominant Discourses in Teaching and Teacher Education. London, Routledge Falmer.

Moore, Alex \& Clarke, Matthew (2016): “'Cruel optimism?’: teacher attachment to professionalism in an era of performativity”. Journal of Education Policy, 31 (5), 666-677, doi: 10.1080/02680939.2016.1160293

Murray, Jean \& Maguire, Meg (2007): "Changes and continuities in teacher education: international perspectives on a gendered field”. Gender and Education, 19 (3), 283-296, doi: 10.1080/09540250701295437

National Council on Teacher Quality (2013). Teacher Prep Review. Washington, DC: NCTQ. 
Roberts, Lorna; Basit, Tehmina N.; McNamara, Olwen; Carrington, Bruce; Maguire, Meg and Woodrow, Derek (2006): "Did they jump or were they pushed? Reasons why minority ethnic trainees withdraw from initial teacher training courses". British Educational Research Journal, 32 (3), 387-410, doi: 10.1080/01411920600635411.

Sachs, Judyth (2001): “Teacher professional identity: competing discourses, competing outcomes.” Journal of Education Policy, 16 (2), 149-161, doi: 10.1080/02680930116819

Sachs, Judyth (2003): “Teacher professional standards: controlling or developing teaching?” Teachers \& Teaching: Theory and Practice, 9 (2), 175-86, doi: 10.1080/13540600309373

Slater, Graham B. (2015): "Education as recovery: neoliberalism, school reform, and the politics of crisis”. Journal of Education Policy, 30 (1), 1-20, doi: 10.1080/02680939.2014.904930

Spencer, Ingrid. (2013): “Doing the 'Second Shift': gendered labour and the symbolic annihilation of teacher educators' work”. Journal of Education for Teaching, 39 (3), 301-313, doi: 10.1080/02607476.2013.799847

Stevens, David (2010): “A Freirean critique of the competence model of teacher education, focusing on the standards for qualified teacher status in England". Journal of education for teaching, 36 (2), 187-196, doi: $10.1080 / 02607471003651722$

Stronach, Ian \& Morris, Brian (1994): "Polemical notes on educational evaluation in the age of "policy hysteria"”. Evaluation \& Research in Education, 8 (1/2), 5-19, doi: 10.1080/09500799409533351

Taylor, C. (2013): “Towards a school-led education system”. Keynote to the North of England education conference, $18^{\text {th }}$ January 2013 (on line). https://www.gov.uk/government/speeches/charlie-taylorskeynote-speech-to-the-north-of-england-education-conference, accessed 2 June 2015.

Teacher Education Ministerial Advisory Group Final Report (TEMAG) (2014): “Action Now: Classroom Ready Teachers". Teacher Education Ministerial Advisory Group Final Report (on line). https:// docs.education.gov.au/system/files/doc/other/action_now_classroom_ready_teachers_accessible. pdf, accessed 11 February 2017.

Whitty, Geoff (2006): “Teacher professionalism in a new era". Paper presented to The First General Teaching Council for Northern Ireland Annual Lecture, Belfast.

Whitty, Geoff (2012): “Changing modes of teacher professionalism: traditional, managerial, collaborative and democratic." in B. Cunningham (ed.). Exploring professionalism. London: Institute of Education.

Whitty, Geoff (2014): "Recent developments in teacher training and their consequences for the 'University Project' in education”. Oxford Review of Education, 40 (4), 466-481, doi: 10.1080/03054985.2014.933007

Whitty, Geoff \& Wisby, Emma (2006): "Moving beyond recent education reform - and towards a democratic professionalism". Hitotsubashi Journal of Social Studies, 38 (1), 43-61.

Zeichner, Ken; Payne, Katherina A. \& Brayko, Kate (2015): “Democratizing Teacher Education”. Journal of Teacher Education, 66 (2), 122-135, doi: 10.1177/0022487114560908 


\section{Biographical note}

Catharine Quirk-Marku is a doctoral candidate at the Educational and Social Research Institute (ESRI) of Manchester Metropolitan University, UK. In 2016, she was awarded a Vice Chancellor's Scholarship to research new forms of teacher education.

Moira Hulme is Professor of Teacher Education at Manchester Metropolitan University, where she leads the Faculty Research Group on Teacher Education: Curriculum, Leadership \& Inclusion. Moira convenes the Teacher Education special interest group of the British Educational Research Association (BERA). 